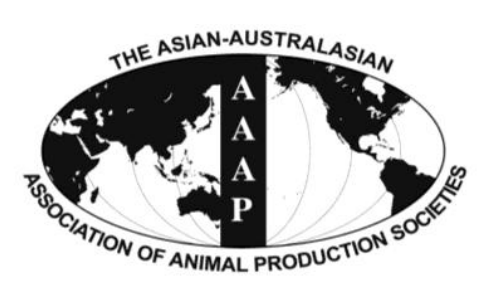

\title{
Ileal Endogenous Amino Acid Flow Response to Nitrogen-free Diets with Differing Ratios of Corn Starch to Dextrose in Pigs
}

\author{
C. Kong, D. Ragland ${ }^{1}$, and O. Adeola* \\ Department of Animal Sciences, Purdue University, West Lafayette, IN 47907-2054, USA
}

\begin{abstract}
The objective of this study was to determine the responses in the digestibility of dry matter (DM) and amino acid (AA) composition of ileal endogenous flow (IEF) of pigs (initial body weight, $69.1 \pm 6.46 \mathrm{~kg}$ ) fed N-free diets (NFD) formulated with different ratios of corn starch to dextrose. Fifteen pigs fitted with a T-cannula at the distal ileum were fed 5 diets according to a triplicated $5 \times 2$ incomplete Latin-square design. Each period consisted of a 5-d adjustment period and $2 \mathrm{~d}$ of ileal digesta collection for $12 \mathrm{~h}$ on each of d 6 and 7 and between each period, there was a 5-d recovery period to avoid abnormal weight loss. The ratios of corn starch to dextrose investigated were 0:879, 293:586, 586:293, 779:100, and 879:0 for diet numbers 1, 2, 3, 4 and 5, respectively, and chromic oxide $(5 \mathrm{~g} / \mathrm{kg})$ was used as an indigestible index. Ileal DM digestibility was greater in Diet 1 than that in Diet 4 (89.5\% vs $87.3 \%, \mathrm{p}<0.01$ ) but they were not different from Diet 2,3 , or 5 . The IEF for most of indispensable AA were not different among diets with the exception of Met, in which a lack of corn starch or dextrose gave lower $(p=0.028)$ IEF of Met than diets containing corn starch and dextrose. Likewise, the dispensable AA and total AA in the IEF did not differ among diets. The respective IEF of AA (mg/kg of dry matter intake) in pigs fed Diets 1, 2, 3, 4, or 5 were 301, 434, 377, 477, or 365 for Lys, 61, 89, 71, 87, or 61 for Met, and 477, 590, 472, 520, or 436 for Thr. Proline was the most abundant AA in the IEF followed by Gly, Glu, and Asp and together accounted for approximately $50 \%$ of the total ileal AA flows of pigs fed NFD. In conclusion, the variation in proportion of corn starch and dextrose in a NFD does not largely affect estimates of IEF of N and AA for growing-finishing pigs. (Key Words: Ileal Digestibility, Basal Endogenous Amino Acid Loss, Swine)
\end{abstract}

\section{INTRODUCTION}

Due to the existing limitations for apparent ileal digestibility including lack of additivity and representativeness of specific endogenous losses, respectively, there has been a growing consensus that standardized counterpart is more accurate data for estimating available amino acid (AA) contents in feed ingredients and diets for pigs (Stein et al., 2007). However, it should be considered that values for standardized ileal digestibility (SID) are affected by the estimates of basal endogenous losses (BEL) which may be dependent on several factors including the differences associated with

\footnotetext{
* Corresponding Author: O. Adeola. Tel: +1-765-494-4848, Fax: +1-765-494-9346, E-mail: ladeola@purdue.edu

${ }^{1}$ Department of Veterinary Clinical Sciences, Purdue University, West Lafayette, IN 47907-2054, USA.

Submitted Mar. 31, 2014; Revised May 6, 2014; Accepted May 11, 2014
}

feed ingredients, diet composition and mixing, and sampling and processing methods as well as analytical methods (Jansman et al., 2002; Stein et al., 2007). Depending on dietary AA intake, the relative proportion of basal endogenous loss to total ileal flow varies and increases when dietary AA intake decreases, indicating the difference in the apparent ileal digestibility (AID) of AA possibly caused by the variation of basal endogenous loss. Therefore, there has been a demand to measure the basal endogenous AA losses correctly and several methods have been suggested (Stein et al., 2007; Moughan and Rutherfurd, 2012). Due to the methodological simplicity, the $\mathrm{N}$-free diet (NFD) feeding method has been commonly used for the estimation of basal endogenous AA losses in pigs and corn starch and dextrose or sucrose are widely used as major ingredients in NFD. Although there is a suggested composition of NFD, the ratio of corn starch to dextrose or sucrose varies across studies (Stein et al., 2007; Cozannet et 
al., 2010; Zhai and Adeola, 2011; Li et al., 2013). The variability in formulation of NFD may influence the estimates of the basal endogenous AA losses in pigs (Moughan and Rutherfurd, 2012) and consequently the values for SID of AA. For broilers, Kong and Adeola (2013) reported variations in the ratios of corn starch to dextrose affected estimates of ileal endogenous flows (IEF) of $\mathrm{N}$ and some AA. However, there is a scarcity of data on the variation in AA composition of BEL in pigs fed NFD varying the ratio of corn starch to dextrose. Thus, the objective of the current study was to determine the response in digestibility of dry matter (DM) and the AA composition of IEF of pigs fed NFD formulated with different ratios of corn starch to dextrose.

\section{MATERIALS AND METHODS}

All animal procedures were approved by the Purdue Animal Care and Use Committee.

\section{Pigs and management}

A total of 15 crossbred (Hampshire $\times$ Duroc $\times$ Yorkshire $\times$ Landrace) barrows with average initial body weight $(\mathrm{BW})$ of $69.1 \pm 6.46 \mathrm{~kg}$ were surgically fitted with a simple Tcannula at the distal ileum as described by Dilger et al. (2004). All the pigs were housed in metabolism crates (1.22 by $1.22 \mathrm{~m}$ ) equipped with low-pressure, automatic waterers and 12-h light-dark cycle.

Experimental diets were fed to 15 pigs according to a triplicated $5 \times 2$ incomplete Latin square design with each period lasting $7 \mathrm{~d}$. There were 15 pigs in 3 replicates of 5 pigs per replicate fed the experimental diets over 2 periods of $7 \mathrm{~d}$ per period. Between each period, there was a 5-d recovery period in which pigs received a standard growerfinisher diet to avoid changes in physiology that may arise from prolonged feeding of NFD. Daily feed allowance was set as $3 \%$ of the BW of the lightest pig at the beginning of each period and was divided into 2 equal portions at 0700 and $1700 \mathrm{~h}$. Ileal digesta were collected over $12 \mathrm{~h}$ on each of $\mathrm{d} 6$ and 7. Collection bags were prefilled with $10 \mathrm{~mL}$ of $5 \%$ formic acid to reduce microbial proliferation, and digesta samples were stored at $-20^{\circ} \mathrm{C}$ before processing. The digesta samples were subsequently thawed and pooled within pig in each period, and then subsampled, freeze dried, and ground before chemical analyses.

\section{Diets}

Ingredient composition of the diets is shown in Table 1. The experimental diets consisted of 5 NFD and the ratios of corn starch to dextrose investigated in the NFD were 0:879, 293:586, 586:293, 779:100, and 879:0 for diet numbers 1, 2 , 3 , 4, or 5, respectively. All diets contained calculated dietary electrolyte balance of $57.9 \mathrm{mEq} / \mathrm{kg}$, and solka floc, soybean oil, monocalcium phosphate, $\mathrm{MgO}$, limestone, $\mathrm{NaCl}$, selenium premix, and $\mathrm{K}_{2} \mathrm{CO}_{3}$ at $20,30,30,1,5,3$, 0.5 , and $4 \mathrm{~g} / \mathrm{kg}$, respectively. Vitamin and mineral premixes were supplemented according to NRC (1998) requirements and chromic oxide was incorporated into diets $(5 \mathrm{~g} / \mathrm{kg})$ as an indigestible index.

\section{Chemical analysis}

Dietary and ileal digesta samples were analyzed for AA (method 982.30 E [a, b, c]; AOAC, 2006) and N (method 990.03; AOAC, 2006) at the University of Missouri Experiment Station Chemical Laboratory, USA. Duplicate proximate analyses were performed at Purdue University on diets and ileal digesta samples. Dry matter analysis of samples was performed by drying the samples in a drying oven at $100^{\circ} \mathrm{C}$ for $24 \mathrm{~h}$ (method 934.01; AOAC, 2006). Chromium concentration in the diets and ileal samples was determined using the method of Fenton and Fenton (1979).

\section{Calculations}

Apparent ileal digestibility (\%) of DM and ileal endogenous $\mathrm{N}$ and $\mathrm{AA}$ flow (IEF, $\mathrm{mg} / \mathrm{kg}$ of DM intake) in pigs were calculated using following equations (Kong and Adeola, 2013):

$$
\begin{aligned}
& \operatorname{AID}(\%)=\left[1-\left(C r_{i} / C r_{o}\right) \times\left(N_{o} / N_{i}\right)\right] \times 100 \\
& \operatorname{IEF}(\mathrm{mg} / \mathrm{kg} \mathrm{DMI})=\left(C r_{i} / C r_{o}\right) \times\left(N_{o}\right)
\end{aligned}
$$

where $C r_{i}$ is the concentration of chromium in the diet in $\mathrm{g} / \mathrm{kg}$ DM intake; $C r_{o}$ is the concentration of chromium in the ileal digesta in $\mathrm{g} / \mathrm{kg} \mathrm{DM}$ output; $N_{o}$ is the concentration of DM, N, or AA in the ileal digesta in $\mathrm{mg} / \mathrm{kg} \mathrm{DM} ; N_{i}$ is the concentration of DM, N, or AA in the diet in $\mathrm{mg} / \mathrm{kg} \mathrm{DM}$.

\section{Statistical analysis}

Apparent ileal DM digestibility and IEF of $\mathrm{N}$ and AA data were analyzed by using the MIXED procedure of SAS. The model consisted of Diet (1 to 5), collection period (1, 2 ), replicate (1 to 3 ), and pig (1 to 15 ) nested within replicate. Tukey's honestly significant difference test was used to compare treatment means with an alpha level of 0.05 .

\section{RESULTS}

Nitrogen content in the Diet 1, 2, 3, 4, 5, corn starch, and dextrose was analyzed to be $0.5,0.5,0.6,0.9,0.9,0.7$, and $0.3 \mathrm{~g} / \mathrm{kg}$, respectively (Table 2). The analyzed individual AA content in the 5 experimental NFD was less than $0.6 \mathrm{~g} / \mathrm{kg}$ of diet. 
Table 1. Ingredient composition of the experimental diets, as-fed basis

\begin{tabular}{|c|c|c|c|c|c|}
\hline \multirow{2}{*}{ Item } & \multicolumn{5}{|c|}{ Dietary treatment No. } \\
\hline & 1 & 2 & 3 & 4 & 5 \\
\hline Corn starch:dextrose & $0: 879$ & $293: 586$ & $586: 293$ & $779: 100$ & $879: 0$ \\
\hline \multicolumn{6}{|l|}{ Ingredient $(\mathrm{g} / \mathrm{kg})$} \\
\hline Corn starch & 0 & 293 & 586 & 779 & 879 \\
\hline Dextrose & 879 & 586 & 293 & 100 & 0 \\
\hline Solkafloc $^{1}$ & 20 & 20 & 20 & 20 & 20 \\
\hline Soybean oil & 30 & 30 & 30 & 30 & 30 \\
\hline Monocalcium phosphate & 30 & 30 & 30 & 30 & 30 \\
\hline Limestone & 5 & 5 & 5 & 5 & 5 \\
\hline $\mathrm{NaCl}$ & 3 & 3 & 3 & 3 & 3 \\
\hline Selenium premix ${ }^{2}$ & 0.5 & 0.5 & 0.5 & 0.5 & 0.5 \\
\hline $\mathrm{MgO}$ & 1 & 1 & 1 & 1 & 1 \\
\hline $\mathrm{K}_{2} \mathrm{CO}_{3}$ & 4 & 4 & 4 & 4 & 4 \\
\hline Vitamin premix $^{3}$ & 1.5 & 1.5 & 1.5 & 1.5 & 1.5 \\
\hline Mineral premix ${ }^{4}$ & 1 & 1 & 1 & 1 & 1 \\
\hline Chromic oxide premix ${ }^{5}$ & 25 & 25 & 25 & 25 & 25 \\
\hline Total & 1,000 & 1,000 & 1,000 & 1,000 & 1,000 \\
\hline \multicolumn{6}{|l|}{ Calculated composition } \\
\hline DE (kcal/kg) & 3,216 & 3,403 & 3,591 & 3,715 & 3,779 \\
\hline $\mathrm{ME}(\mathrm{kcal} / \mathrm{kg})$ & 3,118 & 3,330 & 3,542 & 3,682 & 3,755 \\
\hline $\mathrm{CP}(\mathrm{g} / \mathrm{kg})$ & 1.4 & 2.2 & 3.0 & 3.6 & 3.9 \\
\hline $\mathrm{Ca}(\mathrm{g} / \mathrm{kg})$ & 6.55 & 6.55 & 6.55 & 6.55 & 6.55 \\
\hline $\mathrm{nPP}(\mathrm{g} / \mathrm{kg})$ & 6.30 & 6.30 & 6.30 & 6.30 & 6.30 \\
\hline Electrolyte balance, $\mathrm{mEq}^{6}$ & 57.9 & 57.9 & 57.9 & 57.9 & 57.9 \\
\hline
\end{tabular}

DE, digestible energy; ME, metabolizable energy; CP, crude protein; nPP, non-phytate phosphorus.

${ }^{1}$ Purified cellulose (International Fiber Corp., North Tonawanda, NY, USA).

${ }^{2}$ Supplied $0.3 \mathrm{mg}$ of Se per kilogram of diet.

${ }^{3}$ Vitamin premix supplied per kilogram of diet: vitamin A, 2,423 IU; vitamin $\mathrm{D}_{3}, 242 \mathrm{IU}$; vitamin E, $17.6 \mathrm{IU}$; vitamin K activity, 2.4 mg; menadione, 804 $\mu \mathrm{g}$; vitamin $\mathrm{B}_{12}, 14.1 \mu \mathrm{g}$; riboflavin, $2.8 \mathrm{mg}$; D-pantothenic acid, $9 \mathrm{mg}$; niacin, $13 \mathrm{mg}$.

${ }^{4}$ Mineral premix supplied per kilogram of diet: $\mathrm{Cu}$ (as copper sulfate), $9 \mathrm{mg}$; I (as calcium iodate), $0.34 \mathrm{mg}$; Fe (as ferrous sulfate), $97 \mathrm{mg}$; Mn (as manganese oxide), $12 \mathrm{mg}$; and $\mathrm{Zn}$ (as zinc oxide), $97 \mathrm{mg}$.

${ }^{5}$ Prepared as $1 \mathrm{~g}$ chromic oxide added to $4 \mathrm{~g}$ solka floc.

${ }^{6}$ Calculated as $\mathrm{K}+\mathrm{Na}-\mathrm{Cl}$ in $\mathrm{mEq}$.

The apparent ileal DM digestibility and basal endogenous $\mathrm{N}$ and AA losses of pigs fed NFD with varying proportion of corn starch and dextrose are shown in Table 3. The apparent ileal DM digestibility was grater in Diet 1 than Diet $4(89.5 \%$ vs $87.3 \%, \mathrm{p}<0.01)$ but Diet 1 and 4 were not different from Diet 2, 3, or 5 .

Ileal endogenous $\mathrm{N}$ flow ( $\mathrm{mg} / \mathrm{kg}$ of $\mathrm{DMI})$ ranged from 1,776 (Diet 1) to 2,513 (Diet 4) and did not differ by various NFD. The IEF of all indispensable AA were not different among diets with the exception of Met, which was different among diets $(p=0.028)$ but their means were not separated by Tukey's test. The respective IEF of AA $(\mathrm{mg} / \mathrm{kg}$ of DMI) in pigs fed Diets $1,2,3,4$, or 5 were 301 , $434,377,477$,or 365 for Lys, 61, 89, 71, 87, or 61 for Met, and $477,590,472,520$, or 436 for Thr. Similar to the result for the IEF of indispensable AA, there was no difference in the IEF of dispensable and total AA among diets. Table 4 shows the ratio of individual AA to Lys in IEF of pigs fed NFD with different proportions of corn starch and dextrose.
Met (0.17 to 0.21$)$ and Pro (6.01 to 8.14) are the least and the most abundant AA in IEF for all the dietary treatments, respectively.

\section{DISCUSSION}

The factors affecting the variation in the basal endogenous AA losses between and within laboratories have been described by several researchers (Jansman et al., 2002; Stein et al., 2007; Adedokun et al., 2011), which include the differences associated with feed ingredients, diet composition and mixing, and sampling and processing methods as well as analytical methods. Based on the reported possible variations caused by the structural differences between major ingredients of NFD (Kong and Adeola, 2013), the IEF of AA in pigs fed NFD with various corn starch to dextrose ratios were evaluated in the current study.

The analyzed individual AA contents of 5 NFD used in 
Table 2. Analyzed AA, and CP composition of the experimental diets and ingredients, as-fed basis

\begin{tabular}{|c|c|c|c|c|c|c|c|}
\hline \multirow{2}{*}{ Item } & \multicolumn{5}{|c|}{ Dietary treatment No. } & \multicolumn{2}{|c|}{ Ingredient } \\
\hline & 1 & 2 & 3 & 4 & 5 & Cornstarch & Dextrose \\
\hline Corn starch:dextrose & $0: 879$ & $293: 586$ & $586: 293$ & $779: 100$ & 879:0 & & \\
\hline $\mathrm{N}(\mathrm{g} / \mathrm{kg})$ & 0.5 & 0.5 & 0.6 & 0.9 & 0.9 & 0.7 & 0.3 \\
\hline \multicolumn{8}{|c|}{ Indispensable AA (g/kg) } \\
\hline $\operatorname{Arg}$ & 0.0 & 0.0 & 0.1 & 0.1 & 0.2 & 0.1 & 0.0 \\
\hline His & 0.0 & 0.0 & 0.0 & 0.0 & 0.1 & 0.0 & 0.0 \\
\hline Ile & 0.0 & 0.0 & 0.1 & 0.1 & 0.2 & 0.1 & 0.0 \\
\hline Leu & 0.0 & 0.1 & 0.2 & 0.2 & 0.4 & 0.3 & 0.0 \\
\hline Lys & 0.0 & 0.1 & 0.1 & 0.1 & 0.2 & 0.1 & 0.0 \\
\hline Met & 0.0 & 0.0 & 0.0 & 0.0 & 0.1 & 0.1 & 0.0 \\
\hline Phe & 0.0 & 0.1 & 0.1 & 0.1 & 0.2 & 0.2 & 0.0 \\
\hline Thr & 0.0 & 0.0 & 0.1 & 0.1 & 0.1 & 0.1 & 0.0 \\
\hline Trp & 0.3 & 0.3 & 0.3 & 0.3 & 0.3 & 0.0 & 0.0 \\
\hline Val & 0.0 & 0.0 & 0.0 & 0.1 & 0.2 & 0.2 & 0.0 \\
\hline \multicolumn{8}{|l|}{ Dispensable AA (g/kg) } \\
\hline Ala & 0.0 & 0.1 & 0.1 & 0.1 & 0.2 & 0.2 & 0.0 \\
\hline Asp & 0.0 & 0.1 & 0.1 & 0.1 & 0.3 & 0.2 & 0.0 \\
\hline Cys & 0.0 & 0.0 & 0.0 & 0.0 & 0.1 & 0.1 & 0.0 \\
\hline Glu & 0.0 & 0.1 & 0.3 & 0.3 & 0.6 & 0.1 & 0.1 \\
\hline Gly & 0.0 & 0.1 & 0.1 & 0.1 & 0.2 & 0.1 & 0.0 \\
\hline Pro & 0.2 & 0.3 & 0.4 & 0.4 & 0.5 & 0.2 & 0.0 \\
\hline Ser & 0.0 & 0.0 & 0.1 & 0.1 & 0.1 & 0.1 & 0.0 \\
\hline Tyr & 0.0 & 0.0 & 0.1 & 0.1 & 0.1 & 0.1 & 0.0 \\
\hline Total AA (g/kg) & 0.8 & 1.6 & 2.5 & 2.5 & 4.3 & 2.4 & 0.2 \\
\hline
\end{tabular}

AA, amino acid; $\mathrm{CP}$, crude protein.

Table 3. Ileal DM digestibility and ileal endogenous $\mathrm{N}$ and amino acid flow of pigs fed $\mathrm{N}$-free diets with different proportions of corn starch and dextrose

\begin{tabular}{|c|c|c|c|c|c|c|c|}
\hline \multirow{2}{*}{ Item } & \multicolumn{5}{|c|}{ Dietary treatment } & \multirow{2}{*}{ SEM } & \multirow{2}{*}{$\mathrm{p}$-value } \\
\hline & 1 & 2 & 3 & 4 & 5 & & \\
\hline Corn starch:dextrose & $0: 879$ & $293: 586$ & $586: 293$ & $779: 100$ & $879: 0$ & & \\
\hline Ileal DM digestibility (\%) & $89.5^{\mathrm{a}}$ & $87.9^{\mathrm{ab}}$ & $88.0^{\mathrm{ab}}$ & $87.3^{\mathrm{b}}$ & $88.7^{\mathrm{ab}}$ & 0.57 & $<0.01$ \\
\hline \multicolumn{8}{|c|}{ Ileal endogenous flow (mg/kg of DMI) } \\
\hline $\mathrm{N}$ & 1,776 & 2,207 & 2,045 & 2,513 & 1,925 & 231.4 & 0.065 \\
\hline \multicolumn{8}{|l|}{ Indispensable AA } \\
\hline Arg & 338 & 454 & 404 & 577 & 413 & 70.3 & 0.103 \\
\hline His & 138 & 192 & 162 & 183 & 159 & 23.2 & 0.279 \\
\hline Ile & 246 & 333 & 273 & 319 & 250 & 32.2 & 0.092 \\
\hline Leu & 438 & 589 & 473 & 550 & 420 & 64.3 & 0.157 \\
\hline Lys & 301 & 434 & 377 & 477 & 365 & 67.0 & 0.282 \\
\hline Met & $61^{\mathrm{a}}$ & $89^{\mathrm{a}}$ & $71^{\mathrm{a}}$ & $87^{\mathrm{a}}$ & $61^{\mathrm{a}}$ & 8.2 & 0.028 \\
\hline Phe & 253 & 344 & 275 & 322 & 245 & 35.8 & 0.120 \\
\hline Thr & 477 & 590 & 472 & 520 & 436 & 55.9 & 0.226 \\
\hline $\operatorname{Trp}$ & 128 & 146 & 148 & 166 & 137 & 11.6 & 0.126 \\
\hline Val & 415 & 547 & 447 & 516 & 395 & 52.5 & 0.107 \\
\hline \multicolumn{8}{|l|}{ Dispensable AA } \\
\hline Ala & 374 & 502 & 431 & 539 & 404 & 55.3 & 0.069 \\
\hline Asp & 586 & 826 & 686 & 777 & 623 & 82.7 & 0.113 \\
\hline Cys & 143 & 187 & 146 & 163 & 133 & 23.9 & 0.302 \\
\hline Glu & 693 & 940 & 782 & 928 & 706 & 101.3 & 0.134 \\
\hline Gly & 800 & 1,183 & 996 & 1,166 & 1,031 & 163.9 & 0.252 \\
\hline Pro & 1,812 & 2,634 & 2,919 & 3,668 & 2,971 & 773.3 & 0.325 \\
\hline Ser & 422 & 529 & 430 & 489 & 419 & 51.5 & 0.303 \\
\hline Tyr & 214 & 291 & 234 & 272 & 210 & 31.4 & 0.173 \\
\hline
\end{tabular}

DM, dry matter; SEM, standard error of the mean; DMI, dry matter intake; AA, amino acid.

${ }^{\mathrm{a}, \mathrm{b}}$ Within a row, means without a common superscript differ $(\mathrm{p}<0.05)$. 
Table 4. Ratio of individual AA to lysine in ileal endogenous flow of pigs fed N-free diets with different proportions of corn starch and dextrose $^{1}$

\begin{tabular}{|c|c|c|c|c|c|c|c|c|}
\hline \multirow[b]{2}{*}{ Item } & \multicolumn{5}{|c|}{ Current data } & \multicolumn{3}{|c|}{ Published data } \\
\hline & 1 & 2 & 3 & 4 & 5 & $\begin{array}{c}\text { Zhai and Adeola, } \\
2011\end{array}$ & $\begin{array}{l}\text { Stein et al., } \\
2005\end{array}$ & $\begin{array}{l}\text { Zhang et al., } \\
2002^{2}\end{array}$ \\
\hline Corn starch:dextrose & $0: 879$ & $293: 586$ & $586: 293$ & 779:100 & 879:0 & $768: 100$ & $784: 100$ & $686: 200$ \\
\hline Initial BW (kg) & & & $69.1 \pm 6.46$ & & & $47.1 \pm 1.0$ & $92.1 \pm 3.19$ & $65 \pm 1.85$ \\
\hline \multicolumn{9}{|l|}{ Indispensable AA } \\
\hline Arg & 1.12 & 1.04 & 1.07 & 1.21 & 1.13 & 1.04 & 0.92 & 1.00 \\
\hline His & 0.46 & 0.44 & 0.43 & 0.38 & 0.43 & 0.39 & 0.39 & 0.39 \\
\hline Ile & 0.82 & 0.77 & 0.73 & 0.67 & 0.69 & 0.63 & 0.86 & 0.74 \\
\hline Leu & 1.45 & 1.36 & 1.26 & 1.15 & 1.15 & 1.08 & 1.35 & 1.42 \\
\hline Lys & 1.00 & 1.00 & 1.00 & 1.00 & 1.00 & 1.00 & 1.00 & 1.00 \\
\hline Met & 0.20 & 0.21 & 0.19 & 0.18 & 0.17 & 0.15 & 0.24 & 0.58 \\
\hline Phe & 0.84 & 0.79 & 0.73 & 0.68 & 0.67 & 0.63 & 0.80 & 0.84 \\
\hline Thr & 1.58 & 1.36 & 1.25 & 1.09 & 1.19 & 1.00 & 1.12 & 1.65 \\
\hline $\operatorname{Trp}$ & 0.42 & 0.34 & 0.39 & 0.35 & 0.38 & 0.24 & 0.20 & 1.29 \\
\hline Val & 1.38 & 1.26 & 1.19 & 1.08 & 1.08 & 0.91 & 1.08 & 0.35 \\
\hline \multicolumn{9}{|l|}{ Dispensable AA } \\
\hline Ala & 1.24 & 1.16 & 1.15 & 1.13 & 1.11 & 1.08 & 0.67 & 1.90 \\
\hline Asp & 1.94 & 1.90 & 1.82 & 1.63 & 1.71 & 1.52 & 0.93 & 2.03 \\
\hline Cys & 0.47 & 0.43 & 0.39 & 0.34 & 0.37 & 0.32 & 0.28 & 1.32 \\
\hline Glu & 2.30 & 2.16 & 2.08 & 1.94 & 1.94 & 1.73 & 1.21 & 2.68 \\
\hline Gly & 2.65 & 2.72 & 2.64 & 2.44 & 2.83 & 2.60 & 1.06 & 3.29 \\
\hline Pro & 6.01 & 6.07 & 7.75 & 7.68 & 8.14 & 7.45 & 2.47 & 5.45 \\
\hline Ser & 1.40 & 1.22 & 1.14 & 1.03 & 1.15 & 0.82 & 0.49 & 1.42 \\
\hline Tyr & 0.71 & 0.67 & 0.62 & 0.57 & 0.57 & 0.51 & 0.35 & 0.48 \\
\hline
\end{tabular}

AA, amino acid; BW, body weight.

${ }^{1}$ Ratios calculated as basal endogenous losses of individual AA divided by respective Lys loss.

${ }^{2}$ Corn starch:sucrose.

the current study ranged 0 to $0.6 \mathrm{~g} / \mathrm{kg}$ which was a trace amount and close to the formulated value at $0 \mathrm{~g} / \mathrm{kg}$. Although there is a starch separating process which separates residual protein from starch by using multistephydrocyclone washing process, trace residual protein still exists $(<0.5 \%)$ in the final product of corn starch (Corn Refiners Association, 2013).

The results obtained from the current study showed that AID of DM was greater in Diet 1 than Diet 4 but they were not different from Diet 2, 3, or 5. Because of the relative simple chemical structure of dextrose compared with corn starch (monosaccharide vs polysaccharide) and the digestion and absorption process of these major ingredients, it was hypothesized that a linear decrease in the AID of DM as the proportion of corn starch in NFD increased from 0 to $879 \mathrm{~g} / \mathrm{kg}$. Our previous broiler chicken study (Kong and Adeola, 2013) showed that the AID of DM decreased as the proportion of corn starch in NFD increased. The inconsistent results may be attributed to the differences in the digesta transit time between the 2 species. In general, pigs have a longer total tract digesta transit time than that of broilers when the transit time was determined with an indigestible marker (Kim et al., 2007; Wilfart et al., 2007; Hughes, 2008) and the transit time in pigs may be long enough to assimilate the corn starch in NFD to smaller molecules before absorption. In addition, the difference between the lowest and highest DM digestibility was determined to be $10.1 \%$ and $2.2 \%$ for broiler and pig studies, respectively. The average AID of DM (88.3\%) in the current study was very close to the highest values determined in the previous study at $88.0 \%$.

In the current study, the IEF of indispensable AA ranged from 61 (Met, Diet 1) to $590 \mathrm{mg} / \mathrm{kg}$ (Thr, Diet 2), which was close to the average range obtained in data from 34 reported studies that used ileal cannulated pigs and NFD to measure the IEF of crude protein and AA (Park et al., 2013). The results from the current study indicated that the variation in proportion of corn starch and dextrose in the experimental NFD did not affect the IEF of N and AA at the terminal ileum of growing-finishing pigs. This is not consistent with the results from the broiler study which showed the difference in the IEF of AA (Kong and Adeola, 2013). In the previous study, the inefficient digestive enzyme reutilization (Rothman et al., 2002) was speculated to explain the variation in the IEF of AA for broilers fed various NFD, however the speculation may not extend to pigs due to the relatively longer transition time of digesta in the digestive tract of pigs compared with broilers. Kong and 
Adeola (2013) showed the impact of variation in the IEF on the correction for the apparent ileal AA digestibility. Although the current study showed that there was no difference in the IEF of AA in pigs fed various NFD, there is still a considerable risk when the numerically different values (e.g., values from Diet 1 vs 4 ) are applied to correct the apparent ileal AA digestibility to standardized counterpart. Therefore, caution should be exercised when the values are practically used and it would be still worth having a standard NFD to minimize any possible variation in IEF of AA between studies until more information becomes available.

In the current study, the analysis of variance indicated that the IEF of Met differ by the variation of NFD, however Tukey's test used for mean separation showed a lack of difference among the means because of the large variation in the data set. Park et al. (2013) showed that the BEL of Met had the greatest variability among experiments which used NFD to determine the BEL of AA. This may be due to the determination limit for Met in concert with the relatively low concentration of Met in the IEF compared with other AA.

Proline was the most abundant AA in the IEF followed by Gly, Glu, and Asp which was in agreement with the data reported from studies used growing-finishing pigs fed NFD (Zhang et al., 2002; Zhai and Adeola, 2011). Those abundant AA together accounted for 49.6, 51.6, 55.3, 55.8, and $56.9 \%$ of the total AA flows for Diets 1, 2, 3, 4, and 5, respectively, and these values were comparable to the results from previous studies $(48.3 \%$, Zhang et al., 2002; 57.2\%, Zhai and Adeola, 2011). The sources of endogenous AA includes salivary and digestive secretion, epithelial cell turnover as well as mucin secretion in the gut (Nyachoti et al., 1997), thus the AA composition of the IEF would be dependent on the AA composition of these sources. Although there is an indication of the overestimation of IEF for Pro and Gly (de Lange et al., 1989; Moughan and Rutherfurd, 2012), Hofmann et al. (2010) and Bennick (1982) indicated that glycoproteins excreted with bile and saliva contain relatively large amounts of Gly and Pro. In addition, mucins accounted for approximately $11 \%$ of endogenous protein in ileal digesta of pigs with $\mathrm{Thr}$ contributing $30 \%$ to mucin protein (Lien et al., 1997). In the current study, Thr was the most abundant AA followed by Leu among indispensable AA regardless of the NFD used, and this was in agreement of the collective data derived from 34 research papers (Park et al., 2013). Moreover, the AA profile in relation to Lys in the IEF determined with 5 NFD in the current study was fairly comparable to the respective ratios determined with same methodology in the same laboratory (Zhai and Adeola, 2011) indicating that the ratio of AA to Lys in IEF may be stable with the same methodology regardless of the ratio of corn starch to dextrose in the NFD.

In conclusion, the results in the current study showed that the variation in the composition of a NFD, especially the proportion of corn starch and dextrose did not affect the IEF of AA in pigs. However, considering that the impact of variation in the IEF observed in the current study could be important when IEF is used in correcting AID, it is imperative to standardize the corn starch to dextrose ratio in NFD to minimize any possible variation in the IEF of AA across studies.

\section{REFERENCES}

Adedokun, S. A., O. Adeola, C. M. Parsons, M. S. Lilburn, and T. J. Applegate. 2011. Factors affecting endogenous amino acid flow in chickens and the need for consistency in methodology. Poult. Sci. 90:1737-1748.

AOAC. 2006. Official Methods of Analysis. 18th ed. Association Official Analytical Chemists, Washington, DC, USA.

Bennick, A. 1982. Salivary proline-rich proteins. Mol. Cell. Biochem. 45:83-99.

Cozannet, P., Y. Primot, C. Gady, J. P. Métayer, P. Callu, M. Lessire, F. Skiba, and J. Noblet. 2010. Ileal digestibility of amino acids in wheat distillers dried grains with solubles for pigs. Anim. Feed Sci. Technol. 158:177-186.

Corn Refiners Association. 2013. Corn starch. http://www.corn.org/wp-content/uploads/2013/12/StarchBook let2013.pdf. Accessed March 17, 2014.

de Lange, C. F. M., W. C. Saucer, R. Mosenthin, and W. B. Souffrant. 1989. The effect of feeding different protein-free amino acid composition of endogenous protein collected from the distal ileum and feces in pigs. J. Anim. Sci. 67:746-754.

Dilger, R. N., J. S. Sands, D. Ragland, and O. Adeola. 2004. Digestibility of nitrogen and amino acids in soybean meal with added soyhulls. J. Anim. Sci. 82:715-724.

Fenton, T. W. and M. Fenton. 1979. An improved procedure for the determination of chromic oxide in feed and feces. Can. J. Anim. Sci. 59:631-634.

Hofmann, A. F., L. R. Hagey, and M. D. Krasowski. 2010. Bile salts of vertebrates: structural variation and possible evolutionary significance. J. Lipid Res. 51:226-246.

Hughes, R. J. 2008. Relationship between digesta transit time and apparent metabolisable energy value of wheat in chickens. Br. Poult. Sci. 49:716-720.

Jansman, A. J. M., W. Smink, P. van Leeuwen, and M. Rademacher. 2002. Evaluation through literature data of the amount and amino acid composition of basal endogenous crude protein at the terminal ileum of pigs. Anim. Feed Sci. Technol. 98:49-60.

Kim, B. G., M. D. Lindemann, G. L. Cromwell, A. Balfagon, and J. H. Agudelo. 2007. The correlation between passage rate of digesta and dry matter digestibility in various stages of swine. Livest. Sci. 109:81-84.

Kong, C. and O. Adeola. 2013. Ileal endogenous amino acid flow response to nitrogen-free diets with differing ratios of corn starch to dextrose in broiler chickens. Poult. Sci. 92:1276-1282.

Li, S. F., Y. B. Niu, J. S. Liu, L. Lu, L. Y. Zhang, C. Y. Ran, M. S. Feng, B. Du, J. L. Deng, and X. G. Luo. 2013. Energy, amino 
acid, and phosphorus digestibility of phytase transgenic corn for growing pigs. J. Anim. Sci. 91:298-308.

Lien, K. A., W. C. Sauer, and M. Fenton. 1997. Mucin output in ileal digesta of pigs fed a protein-free diet. Z. Ernährungswiss. 36:182-190.

Moughan, P. J. and S. M. Rutherfurd. 2012. Gut luminal endogenous protein: Implications for the determination of ileal amino acid digestibility in humans. Br. J. Nutr. 108:S258-S263.

NRC. 1998. Nutrient Requirements of Swine. 10th ed. National Academy Press, Washington, DC, USA.

Nyachoti, C. M., C. F. M. de Lange, B. W. McBride, and H. Schulze. 1997. Significance of endogenous gut nitrogen losses in the nutrition of growing pigs: A review. Can. J. Anim. Sci. 77:149-163.

Park, C. S, S. I. Oh, and B. G. Kim. 2013. Prediction of basal endogenous losses of amino acids based on body weight and feed intake in pigs fed nitrogen-free diets. Rev. Colomb. Cienc. Pecu. 26:186-192.

Rothman, S., C. Liebow, and L. Isenman. 2002. Conservation of digestive enzymes. Physiol. Rev. 82:1-18.
Stein, H. H., C. Pedersen, A. R. Wirt, and R. A. Bohlke. 2005. Additivity of values for apparent and standardized ileal digestibility of amino acids in mixed diets fed to growing pigs. J. Anim. Sci. 83:2387-2395.

Stein, H. H., B. Sève, M. F. Fuller, P. J. Moughan, and C. F. M. de Lange. 2007. Invited review: Amino acid bioavailability and digestibility in pig feed ingredients: Terminology and application. J. Anim. Sci. 85:172-180.

Wilfart, A., L. Montagne, H. Simmins, J. Noblet, and J. van Milgen. 2007. Digesta transit in different segments of the gastrointestinal tract of pigs as affected by insoluble fibre supplied by wheat bran. Br. J. Nutr. 98:54-62.

Zhai, H. and O. Adeola. 2011. Apparent and standardized ileal digestibilities of amino acids for pigs fed corn- and soybean meal-based diets at varying crude protein levels. J. Anim. Sci. 89:3626-3633.

Zhang, Y., D. Li, S. Fan, X. Piao, J. Wang, and I. K. Han. 2002. Effects of casein and protein-free diets on endogenous amino acid losses in pigs. Asian Australas. J. Anim. Sci.15:1634-1638. 